\title{
Plutonium in Surface Soil Near the Southwestern Boundary of the Hanford Project
}

\author{
K. R. Price
}

R. L. Dirkes

May 1981

Prepared for the U.S. Department of Energy under Contract DE-AC06-76RLO 1830

Pacific Northwest Laboratory

Operated for the U.S. Department of Energy

by Battelle Memorial Institute 


\title{
NOT ICE
}

This report was prepared as an account of work sponsored by the United States Government. Neither the United States nor the Department of Energy, nor any of their employees, nor any of their contractors, subcontractors, or their employees, makes any warranty, express or implied, or assumes any legal liability or responsibility for the accuracy, completeness or usefulness of any information, apparatus, product or process disclosed, or represents that its use would not infringe privately owned rights.

The views, opinions and conclusions contained in this report are those of the contractor and do not necessarily represent those of the United States Government or the United States Department of Energy.

\author{
PACIFIC NORTHWEST LABORATORY \\ operated by \\ BATTELLE \\ for the \\ UNITED STATES DEPARTMENT OF ENERGY \\ Under Contract DE-AC06-76RLO 1830
}

\author{
Printed in the United States of America. \\ Available from \\ National Technical Information Service \\ United States Department of Commerce \\ 5285 Port Royal Road \\ Springfield, Virginia 22151
}

Price: Prinled Copy $\$$

$\therefore$ Microfiche $\$ 3.00$

$\begin{array}{cc}\text { PPages } & \begin{array}{c}\text { NTIS } \\ \text { Selling Price }\end{array} \\ & \\ 001-025 & \$ 4.00 \\ 026-050 & \$ 4.50 \\ 051-075 & \$ 5.25 \\ 076-100 & \$ 6.00 \\ 101-125 & \$ 6.50 \\ 126-150 & \$ 7.25 \\ 151-175 & \$ 8.00 \\ 176-200 & \$ 9.00 \\ 201-225 & \$ 9.25 \\ 226-250 & \$ 9.50 \\ 251-275 & \$ 10.75 \\ 276-300 & \$ 11.00\end{array}$


PLUTONIUM IN SURFACE SOIL NEAR THE SOUTHWESTERN BOUNDARY OF THE HANFORD PROJECT

K. R. Price

R. L. Dirkes

May 1981

Prepared for the U.S. Department of Energy under Contract DE-AC06-76RL0-1830

Pacific Northwest Laboratory Richland, Washington 99352 
Samples of airborne particles collected near the Prosser Barricade in another study showed $10 \mathrm{w}{ }^{240} \mathrm{Pu} /{ }^{239} \mathrm{Pu}$ ratios that are indicative of Hanfordproduced plutonium. In an effort to locate evidence of a trail or the remains of a large short-term release of plutonium that may have occurred during past Hanford operations, surface soil samples were collected along the southwestern boundary of the Hanford Site in December 1979.

Results indicated the possibility of slightly elevated levels of $239,240_{\mathrm{Pu}}$ $(0.016 \mathrm{pC} / \mathrm{g})$ occurring in the general vicinity of the Arid Land Ecology Field lab extending to the junction of Highway 240 and Horn Rapids Road as compared to lower levels $(0.006 \mathrm{pCi} / \mathrm{g})$ in a northwesterly direction along the base of Rattlesnake Mountain and the eastern slope of Yakima Ridge. Assuming the wor $1 \mathrm{dwide}$ average ${ }^{240} \mathrm{Pu} /{ }^{239} \mathrm{Pu}$ ratio of 0.18 for soil of the Pacific Northwest, the plutonium in these soil samples may be slightly less enriched with ${ }^{240} \mathrm{Pu}\left({ }^{240} \mathrm{Pu} /{ }^{239} \mathrm{Pu}=0.16\right)$.

No evidence was discovered of an acute release remaining intact and crossing the southwestern boundary during the operating history of plutonium facilities in the 200 Areas. The results of this special study are what one would expect based on knowledge of airborne releases of radioactive materials from Hanford facilities, prevailing wind patterns, and the distribution of airborne contaminants determined in previous studies. 


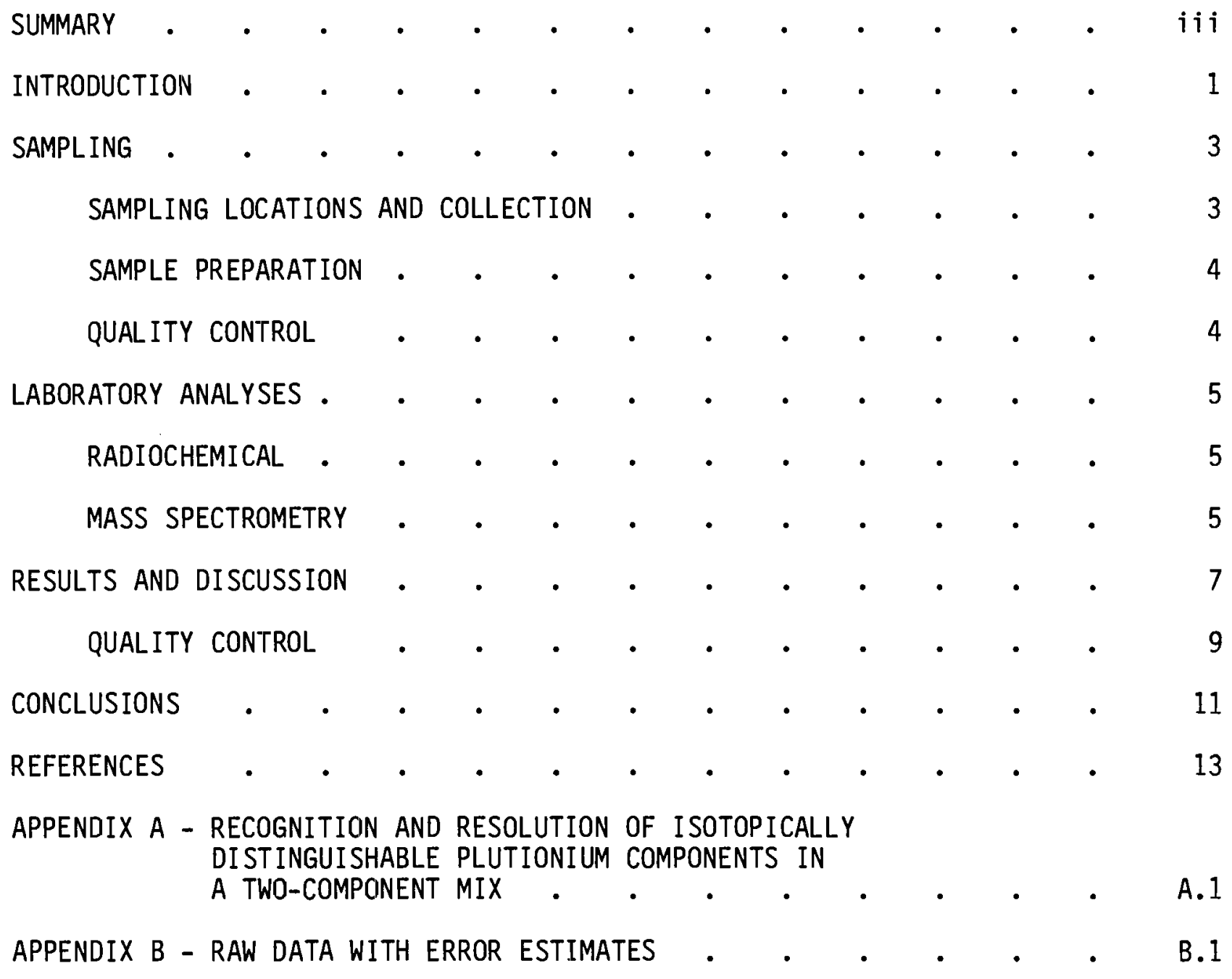




\section{FIGURES}

1 Soil Collection Sites and Sample Composite Numbers . . . 3

\section{TABLES}

1 Plutonium Concentrations and Isotopic Compositions of Surface So il Samples

B.1 Plutonium Concentrations and Isotopic Aton Percents of Surface Soil Samples 


\section{PLUTONIUM IN SUIRFACE SOIL NEAR THE SOUTHWESTERN BOUNDARY OF THE HANFORD PROJECT}

\section{INTRODUCTION}

Data presented by Sehmel (1979) suggested that a significant offsite deposition of plutonium may have resulted from past operations at Hanford. Samples of airborne particles collected near the Prosser Barricade had unusually low ${ }^{240} \mathrm{Pu} /{ }^{239} \mathrm{Pu}$ ratios indicative of plutonium processed in Hanford facilities. Surface soil samples were collected along the southwestern boundary of the Hanford site. This was done in an effort to locate evidence of a trail or the. remains of an acute, hypothetical release of plutonium from the 200 Areas that may have blown offsite in the direction of the Prosser Barricade. Radiochemical analysis for ${ }^{239,240}$ Pu was conducted by U. S. Testing Company, Inc (UST). Isotopic analyses for ${ }^{239} \mathrm{Pu}$ and ${ }^{240} \mathrm{Pu}$ were conducted by the Department of Energy's, Pacific Northwest Laboratory (PNL) Mass Spectrometry Laboratory. Sample collection was performed by PNL's Environmental Monitoring personnel. 
Figure 1 illustrates the approximate locations of 50 surface soil samples that were collected in December 1979, from the southwestern portion of the Hanford Site. Samples were collected about every $0.8 \mathrm{~km}$ along Horn Rapids Road from Highway 240 to the Rattlesnake Mountain road; along the Rattlesnake Mountain road and the $365 \mathrm{~m}$ contour road to Rattlesnake Springs; and along the base of Yakima Ridge to within $0.8 \mathrm{~km}$ of the Yakima Barricade.

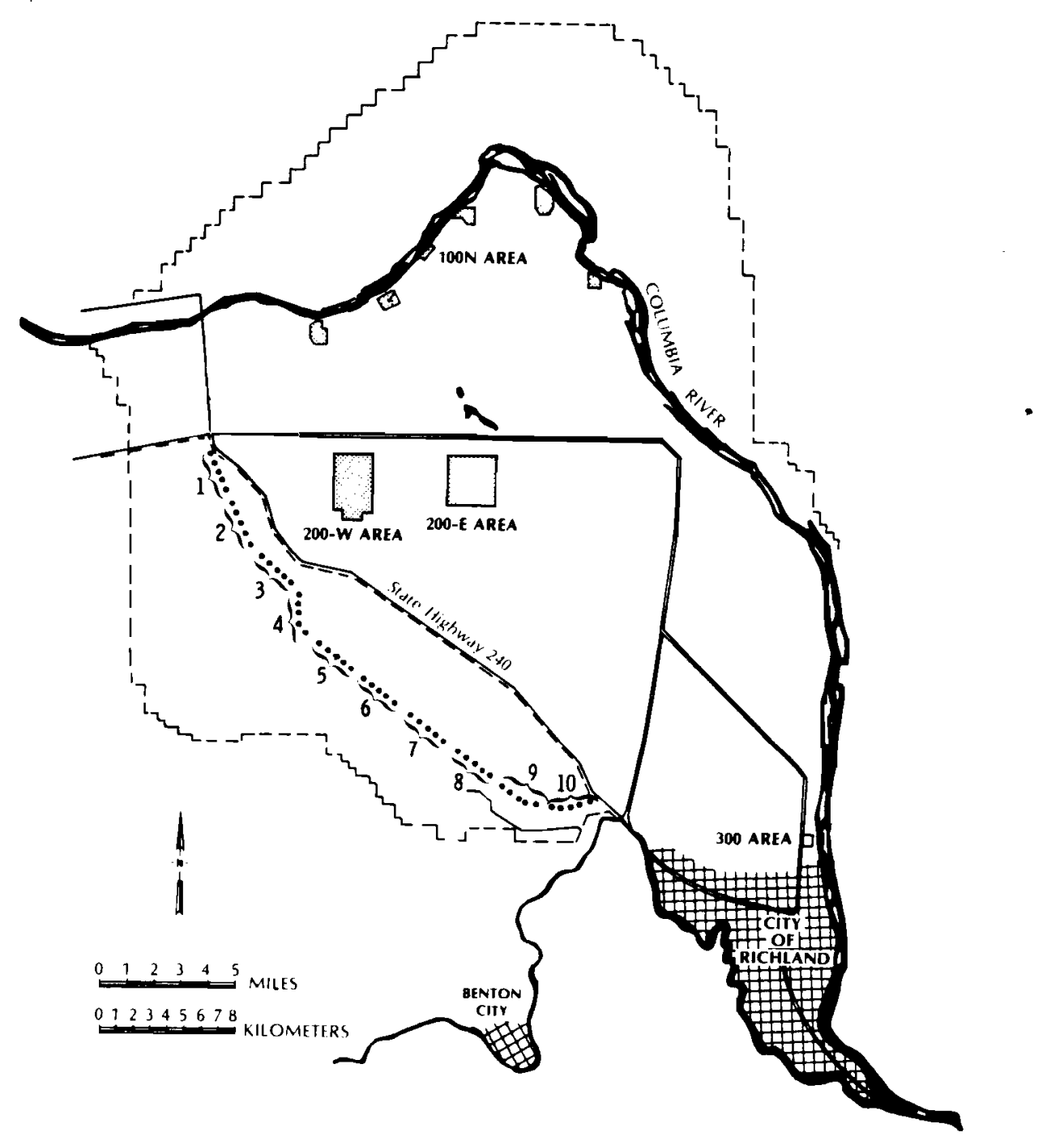

FIGURE 1. Soil Collection Sites and Sample Composite Numbers 
Samples were collected according to the standard sampling procedure (PNL, 1975) with two minor exceptions. First, the samples were collected in cardboard ice cream cartons, rather than plastic bags, to facilitate rapid drying because of the wet condition of the soil at the time of collection. Second, one or two meters distance between individual sample soil plugs were used at each location rather than the standard distance of $10 \mathrm{~m}$ to expedite sampling. The standard procedure calt's for the use of a sampling tool to collect five individual plugs of soil at each sample location. The plugs of soil measured approximately $10 \mathrm{~cm}$ in diameter and $2.5 \mathrm{~cm}$ deep. The plugs of soil were then combined into a single sample.

\section{SAMPLE PREPARATION}

Combined samples were oven dried at $110^{\circ} \mathrm{C}$ for 24 hours. The dried soil was then sifted through a $6 \mathrm{~mm}$ mesh screen to remove stones and organic debris. Portions of dried, screened, and mixed samples from five adjacent sampling locations were composited to reduce the number of samples requiring analysis. Figure 1 also shows the composite sample numbers 1 through 10, and the collection areas they represent. Five hundred grams of each composite sample were submitted to UST for radiochemical plutonium analysis. In addition to the 10 composite samples, two additional aliquotes were prepared for analys is of composite sample numbers three and seven, for a total of three replicates each.

\section{QUALITY CONTROL}

Two blank soil samples and two spiked soil samples were prepared for analysis. The soil used for these samples was collected from the basement of a Richland, WA home constructed prior to 1945 and represents pre-atomic era soil. The blank samples consisted of $500 \mathrm{~g}$ of soil after drying and screening. Spiked samples were prepared with $500 \mathrm{~g}$ of screened and dried soil spiked with $5 \mathrm{ml}$ of $4 \mathrm{~N} \mathrm{HNO}_{3}$ solution containing $5.2 \mathrm{pCi}{ }^{238} \mathrm{Pu}, 50 \mathrm{pCi}{ }^{239} \mathrm{Pu}$ and $4.9 \mathrm{pCi}$ ${ }^{230} \mathrm{Pu}$ in addition to known quantities of other radionuclides. The spiking solution was prepared by the Hanford Engineering Development Laboratory (HEDL) Standards Lab for the PNL Environment Surveillance Program. 


\section{LABORATORY ANAL YSES}

\section{RADIOCHEMICAL}

Eighteen soil samples were submitted to United States Testing Co. (UST) for routine plutonium analysis with one exception. A platinum planchet was used for the electrodeposition step instead of a stainless steel planchet. This was done to enable PNL to perform isotopic analyses. The UST procedure involves leaching the plutonium from the soil, adsorbing the plutonium onto an ion exchange resin, followed by a series of extractions and evaporations. Electrodeposition onto the $\mathrm{planchet}$ is next, followed by alpha spectrometry to determine activity.

\section{MASS SPECTROMETRY}

After radiochemical analysis (UST), the planchets were taken to the PNL Mass Spectrometry Lab for isotopic analyses of ${ }^{239} \mathrm{Pu},{ }^{240} \mathrm{Pu},{ }^{241} \mathrm{Pu}$ and ${ }^{242} \mathrm{Pu}$. The spectrometry procedure has been described (Strebin and Robertson, 1977). 


\section{RADIOCHEMICAL AND SPECTROMETRIC RESULTS AND DISCUSSION}

Table 1 presents radiochemical and spectrometric results for the composite, blank, and spiked samples. The ${ }^{239,240} \mathrm{Pu}$ concentrations are similar to those reported in the CY-1979 Environmental Status Report for the Hanford Site (Houston and Blumer, 1980). What is interesting about the ${ }^{239,240} \mathrm{Pu}$ concentration data is that they appear to fall into two groups (locations 1 through 6 , and 7 through 10). Indeed, the median values for these two groups are $0.006 \mathrm{pCi} / \mathrm{g}$, and $0.016 \mathrm{pCi} / \mathrm{g}$, respectively. The grouping of these data may be the result of our sampling transect intersecting the southwestern edge of a general pattern of airborne deposition, such as that described by Healy, et a1. (1958), for the deposition of ${ }^{131}$ I onto vegetation at Hanford. That is, airborne effluents from the 200 Areas tend to be distributed in a southeasterly direction, with the plume intersecting the most eastern portion of Rattlesnake Mountain. Moreover, the predominant wind direction during a 11 stability classes in the 200 Areas is known to be toward the southeast (ERDA, 1975).

None of the atom ratios support evidence of an aerial distribution pattern, and the median value for the ${ }^{240} \mathrm{Pu} /{ }^{239} \mathrm{Pu}$ ratio of 0.16 may be slightly lower than the worldwide average for soil (0.18) reported by krey et al. (1976). The median value for the ${ }^{241} \mathrm{Pu} /{ }^{242} \mathrm{Pu}$ atom ratio is 1.7 and is within the range of 1.5 to 1.8 for worldwide fallout in surface soil. Thus, the apparent grouping of plutonium concentration data and the possibility of a slightly reduced ${ }^{240} \mathrm{Pu} /{ }^{239} \mathrm{Pu}$ ratio indicate that histroical Hanford atmospheric releases may have influenced the plutonium content in surface soils in some of the areas sampled. Very small amounts of plutonium have been released to the atmosphere from the 200 Areas facilities since 1944 (Anderson, 1974). However, results of this study do not show any evidence of a track or the remains of a major short term release of plutonium over the southwestern boundary of the Hanford Site.

Kelley(a) has suggested a method to recognize and resolve isotopically distingushable plutonium components in multicomponent mixes based on a linear relationship between various plutonium isotopic ratios. If the sample results

(a) See Appendix A 


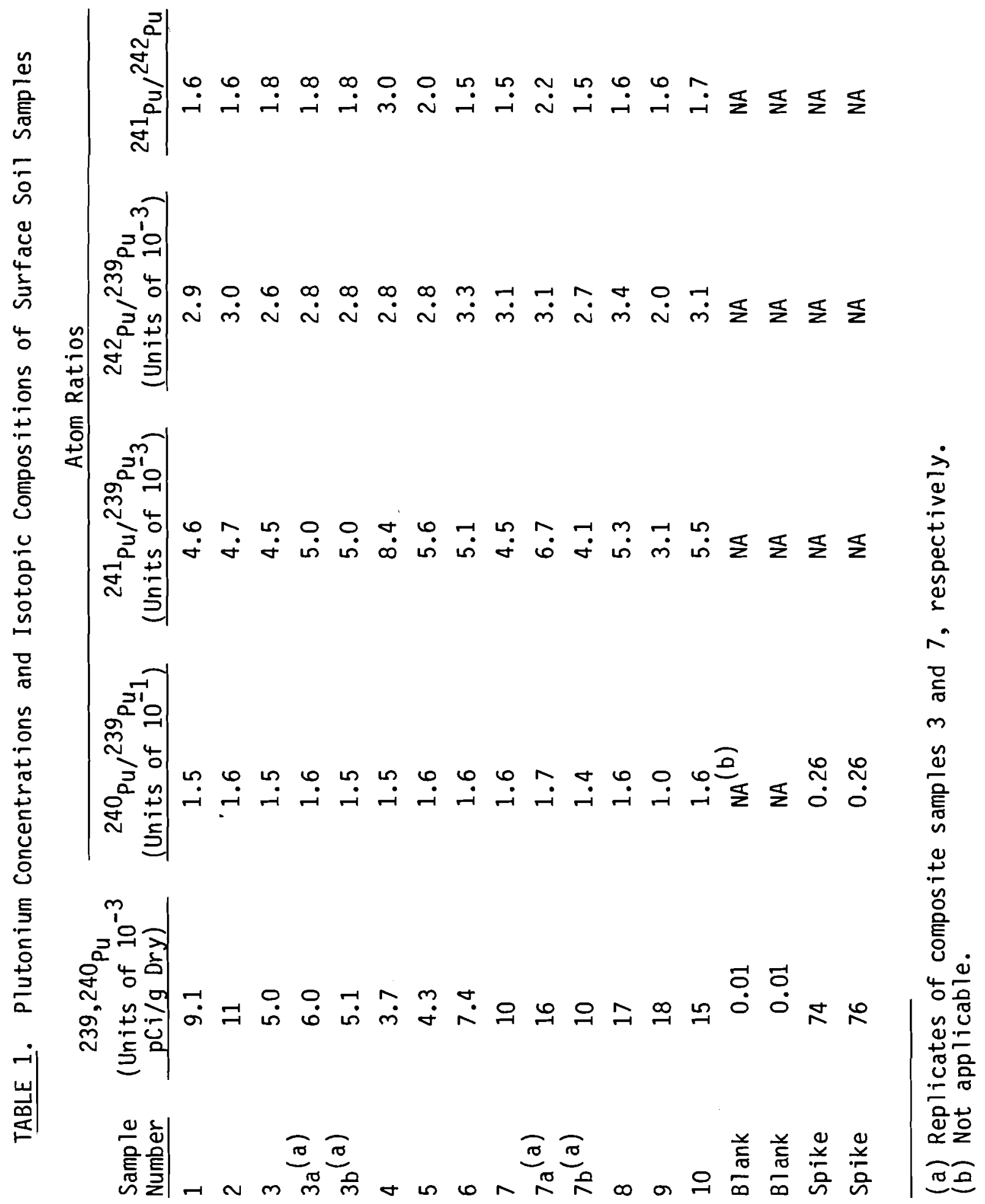


in Table 1 are from samples with two sources of plutonium, i.e., worldwide fallout and Hanford, then pairs of isotopic ratios should show linear relationships. The calculated correlation coefficient, $r^{2}$, for $Y=a+b x$ using ${ }^{240} \mathrm{Pu} /$ ${ }^{239} \mathrm{Pu}$ vs. ${ }^{242} \mathrm{Pu} /{ }^{239} \mathrm{Pu}$ atom ratios is 0.30 , not a very high correlation, and thus not likely that the samples contain plutonium from two sources. The calculated $r^{2}$ value for ${ }^{240} \mathrm{Pu} /{ }^{239} \mathrm{Pu}$ vs. ${ }^{242} \mathrm{Pu} /{ }^{239} \mathrm{Pu}$ is 0.71 , a better correlation. However, there is a lack of consistency between the two correlations. If high correlations were demonstrable, it could be concluded that a two-component mix was likely. The converse statement, that a straight line relationship implies that two and only two components were present, cannot be made. The proportion of at least one component isotope to the total of that isotope present at the sampling site must be known before a two-component mix can be confirmed.

The relationship between these results and those presented by Sehmel (1979) is unclear. These results indicate that there may be elevated levels of $239,249 \mathrm{Pu}$ in sample locations $7,8,9$, and 10 which were essentially upwind from Sehmel's equipment during the periods when air samples were collected. However, ${ }^{240} \mathrm{Pu} /{ }^{239} \mathrm{Pu}$ ratios for soil samples do not indicate the presence of Hanford produced plutonium. If there is a source of Hanford plutonium available for resuspension in the vicinity of Sehmel's air samplers, either the soil samples collected in this study are not from that location, or surface soil sampling in the manner used here is an incorrect means of identifying such a source.

QUALITY CONTROL

Recovery of $239,240 \mathrm{Pu}$ from the spiked samples was fair (68\%), and duplicate results were close. The blank samples yielded essentially no positive counts, as expected. The ${ }^{240} \mathrm{Pu} /{ }^{239} \mathrm{Pu}$ ratio for the spiked samples is very close (110\%) to the calculated value. The radiochemical and mass spectrometry results for replicates of composite samples 3 and 7 , are reasonable even though values may differ by more than $50 \%$. This observed variability emphasizes the need for adequate replication for environmental samples when precise estimates are required. However, the results shown in Table 1 are satisfactory for the purpose of the study. All data, complete with counting errors are given in Appendix B. 
CONCLUSIONS

Results of this study of plutonium in surface soil provide no evidence of a track or the remains of a major short term release of plutonium from past Hanford operations extending over the southwestern boundary of the site. However, the $239,240 \mathrm{Pu}$ concentration data tend to fall into two groups indicative of a possible general deposition of 200 Area airborne effluents in a southeasterly direction. It is emphasized that the data presented in this study are essentially single values of composited samples with no intent to provide statistical validity or confidence limits. Results are of a survey nature and are adequate for the purpose of the study.

Isotopic analyses resulted in ${ }^{240} \mathrm{Pu} /{ }^{239} \mathrm{Pu}$ atom ratios slightly less than the worldwide average, which may indicate some slight influence of plutonium from Hanford sources. However a consistent linear relationship could not be demonstrated for various isotope ratios which would support the hypothesis of a two-source mix of plutonium in these surface soil samples. The relationship between results from this study and those from air samples collected by Sehmel (1979) is unclear. Sehmel's results indicate the possibility of Hanford produced plutonium being resuspended and picked up in air samples collected during southwesterly winds. If that is true, then the results of this study indicate that either these soil samples are not from the area where resuspension is occurring or that surface soil sampling is an incorrect means of identifying such a source of resuspension. 


\section{REFERENCES}

Anderson, J. D. 1974. "Emitted and Decayed Values of Radionuclides in Gaseous Wastes Discharged to the Atmosphere from the Separation Facilities Through Calendar Year 1972." ARH-3026, Atlantic Richfield Hanford Company, Richland, WA.

ERDA. 1975. Waste Management Operations. ERDA 1538, U. S. Energy Research and Development Administration, Washington, D.C.

ERDA. 1975. A1ternatives for Long-Term Management for Defense High-Level Waste, Hanford Reservation. ERDA 77-44, Energy Research and Development Administration, Washington, D.C.

Healy, J. W., B. V. Andersen, H. V. Clukey, and J. K. Soldat. 1958. "Radiation Exposure to People in the Environs of a Major Production Atomic Energy Plant." In Proceedings of the Second UN Geneva Conference, pp. 309-318.

PNL. 1975, "Environmental Monitoring Procedures", PNL-MA-580. Pacific Northwest Laboratory, Richland, WA.

Sehme1, G. A. 1979. "Airborne Plutonium Transported During Southwesterly Winds Near the Hanford Prosser Barricade." PNL-SA-7839. Pacific Northwest Laboratory, Richland, WA.

Strebin, R. S. and D. M. Robertson, 1977. "Isotopic Composition Measurements on Sub-picogram Amounts of Plutonium". Analytica Chemica Acta, 91:267-272.

UST. 1980. "Procedure Manual", UST-RL-PM-9-80, United States Testing Company, Inc., Richland, WA. 
APPENDIX A

RECOGNITION AND RESOLUTION OF ISOTOPICALLY DISTINGUISHABLE PLUTONIUM COMPONENTS IN A TWO COMPONENT MIX 
APPENDIX A

\section{RECOGNITION AND RESOLUTION OF ISOTOPICALLY}

DISTINGUISHABLE PLUTONIUM COMPONENTS IN A TWO COMPONENT MIX

J. M. Kelley

Physical Sciences Department

Pacific Northwest Laboratory

Certain linear relationships facilitate the recognition and resolution of isotopically distinguishable plutonium components in multi-component mixes. In the paragraphs that follow, some of these relationships for the simple case of a two-component mix will be developed. For that purpose, the following notation is adopted:

$$
\begin{aligned}
9 & =\text { Atoms of } 239 \mathrm{Pu} \\
0 & =\text { Atoms of } 240 \mathrm{Pu} \\
1 & =\text { Atoms of } 241 \mathrm{Pu} \\
2 & =\text { Atoms of } 242 \mathrm{Pu} \\
0 / 9 & =240 \mathrm{Pu} / 239 \mathrm{Pu} \text { Atom Ratio } \\
1 / 9 & =241 \mathrm{Pu} / 239 \mathrm{Pu} \text { Atom Ratio } \\
2 / 9 & =242 \mathrm{Pu} / 239 \mathrm{Pu} \text { Atom Ratio }
\end{aligned}
$$

Subscripts $A$ and $B$ will be used to distinguish the components from which atoms originate. $O_{A}$, for example, refers to atoms of component $A 240_{\mathrm{Pu}}$, whereas $O_{B}$ refers to atoms of component $B{ }^{240} \mathrm{Pu}$. Where subscripts are absent, the sum of atoms of both components is implied (i.e., $0=0_{A}+0_{B}$.) A single subscript will be used for atom ratios. That is, $0 / 9_{A}$ implies $0_{A} / 9_{A}$.

In a two-component mix there will be Type $A$ and Type $B$ atoms. Mass spectrometry measurements of a single sample yield atom ratio values that do not distinguish between these types. For example: 


$$
0 / 9=\frac{0_{A}+0_{B}}{{ }_{A}+9_{B}}
$$

where $0 / 9$, being the quantity measured, is known, but $0 / 9_{A}$ and $0 / 9_{B}$ remain unknown.

If, however, the fractional abundance of one component type (e.g., $9_{B} / 9$ ) varies from sample to sample in a manner that can be specified, then $0 / 9$ and $0 / 9_{B}$ can be determined. To show this, Equation (1) is rewritten in the form

$$
0 / 9=0 / 9_{A}+\frac{9 B}{9}\left(0 / 9_{b}-0 / 9_{A}\right)
$$

which, because $0 / 9_{A}$ and $0 / 9_{B}$ are constants, is a linear expression. That is, $0 / 9$ will vary linearly with $9_{B} / 9$. Values for $0 / 9_{A}$ and $0 / 9_{B}$ follow from the intercept and slope of a plot of $0 / 9$ versus $9_{B} / 9$.

Linear expressions for $1 / 9$ and $2 / 9$, which permit resolution of Types $A$ and $B 1 / 9$ and $2 / 9$ components, take exactly the same form as Equation (2), where it is only necessary to substitute 1's or 2's for 0 's.

Equation (2) and the analogous expression describing $1 / 9$ can be solved simultaneously with the result that

$$
0 / 9=k_{1}+k_{2} 1 / 9
$$

here $k_{2}=\left(0 / 9_{B}-0 / 9_{A}\right) /\left(1 / 9_{B}-1 / 9_{A}\right)$ and $k_{1}=0 / 9_{A}-k_{2} 1 / 9_{A}$. Likewise,

$$
0 / 9=k^{\prime}{ }_{1}+k^{\prime}{ }_{2} 2 / 9
$$

where $k^{\prime}{ }_{1}$ and $k^{\prime}{ }_{2}$ take values as in the expressions for $k_{1}$ and $k_{2}$, but with 1 's replaced by 2 's.

Equations (3) and (4) make it clear that plots of $0 / 9$ versus $1 / 9$ (and $2 / 9)$ are linear for two-component mixes. The converse statement, that plots 
describing straight lines imply that two and only two components are present, has not been established. Therefore, while a linear relationship between $0 / 9$ and $1 / 9(2 / 9)$ values must exist if a two-component mix is present, and thus is evidence of such a mix, a linear relationship does not in itself prove that more components are not present. Thus, if Equation (3) is obeyed, then it is on ly likely that a two-component mix is present. However, if Equation (2) is also obeyed, then the presence of a two-component mix is established. 
APPENDIX B

RAW DATA WITH ERROR ESTIMATES 


\section{APPENDIX B}

\section{RAW DATA WITH ERROR ESTIMATES}

\section{TABLE B.1. Plutonium Concentrations and Isotopic Atom Percents}

of Surface Soil Samples

\begin{tabular}{|c|c|c|c|c|c|}
\hline \multirow{2}{*}{$\begin{array}{l}\text { Sample } \\
\text { Number }\end{array}$} & \multirow{2}{*}{$\begin{array}{l}\text { Concentration } \\
239,240 \mathrm{Pu} / \mathrm{g} \text { Dry) }\end{array}$} & \multicolumn{4}{|c|}{ Atom Percent } \\
\hline & & ${ }^{239} \mathrm{Pu}$ & ${ }^{240} \mathrm{Pu}$ & $241_{\mathrm{Pu}}$ & $242 \mathrm{Pu}$ \\
\hline \multirow[t]{2}{*}{1} & 0.00906 & 86.27 & 13.08 & 0.398 & 0.253 \\
\hline & $0.0034^{(a)}$ & 0.06 & 0.06 & 0.012 & 0.016 \\
\hline \multirow[t]{2}{*}{2} & 0.0107 & 86.0 & 13.4 & 0.41 & 0.254 \\
\hline & 0.0021 & 0.2 & 0.2 & 0.2 & 0.016 \\
\hline \multirow[t]{2}{*}{3} & 0.00495 & 86.63 & 12.75 & 0.39 & 0.22 \\
\hline & 0.0013 & 0.12 & 0.12 & 0.02 & 0.02 \\
\hline \multirow[t]{2}{*}{$3 a$} & 0.00604 & 85.75 & 13.59 & 0.43 & 0.239 \\
\hline & 0.0016 & 0.12 & 0.12 & 0.02 & 0.018 \\
\hline \multirow[t]{2}{*}{$3 b$} & 0.00507 & 86.29 & 13.04 & 0.43 & 0.242 \\
\hline & 0.0014 & 0.12 & 0.12 & 0.02 & 0.018 \\
\hline \multirow[t]{2}{*}{4} & 0.00367 & 86.04 & 13.00 & 0.73 & 0.243 \\
\hline & 0.0011 & 0.10 & 0.10 & 0.04 & 0.016 \\
\hline \multirow[t]{2}{*}{5} & 0.00427 & 85.5 & 13.8 & 0.48 & 0.235 \\
\hline & 0.0016 & 0.2 & 0.2 & 0.02 & 0.016 \\
\hline \multirow[t]{2}{*}{6} & 0.00738 & 85.80 & 13.49 & 0.43 & 0.279 \\
\hline & 0.0020 & 0.10 & 0.10 & 0.02 & 0.016 \\
\hline \multirow[t]{2}{*}{7} & 0.0102 & 85.83 & 13.52 & 0.38 & 0.26 \\
\hline & 0.0029 & 0.18 & 0.18 & 0.06 & 0.04 \\
\hline \multirow[t]{2}{*}{$7 a$} & 0.0161 & 84.99 & 14.19 & 0.57 & 0.261 \\
\hline & 0.0025 & 0.14 & 0.14 & 0.02 & 0.018 \\
\hline \multirow[t]{2}{*}{$7 b$} & 0.0101 & 87.59 & 11.82 & 0.357 & 0.235 \\
\hline & 0.0021 & 0.08 & 0.08 & 0.014 & 0.012 \\
\hline \multirow[t]{2}{*}{8} & 0.0166 & 85.40 & 13.86 & 0.449 & 0.289 \\
\hline & 0.0027 & 0.10 & 0.10 & 0.016 & 0.012 \\
\hline \multirow[t]{2}{*}{9} & 0.0178 & 90.16 & 9.38 & 0.283 & 0.182 \\
\hline & 0.0042 & 0.06 & 0.06 & 0.008 & 0.006 \\
\hline \multirow[t]{2}{*}{10} & 0.0152 & 85.8 & 13.5 & 0.47 & 0.27 \\
\hline & 0.0035 & 0.4 & 0.4 & 0.08 & 0.03 \\
\hline \multirow[t]{2}{*}{ Blank } & -0.00028 & 93.0 & 6.2 & $<1$. & $<0.6$ \\
\hline & 0.00025 & 1.6 & 1.0 & -- & - \\
\hline \multirow[t]{2}{*}{ Bl ank } & 0.00017 & 88.4 & 9.7 & 1.73 & 0.17 \\
\hline & 0.00052 & 0.4 & 0.4 & 0.14 & 0.10 \\
\hline \multirow[t]{2}{*}{ Spike } & 0.0742 & 97.46 & 2.53 & $<0.001$ & 0.003 \\
\hline & 0.0083 & 0.04 & 0.04 & -- & 0.001 \\
\hline \multirow[t]{2}{*}{ Spike } & 0.0756 & 97.44 & 2.55 & 0.009 & 0.005 \\
\hline & 0.0064 & 0.04 & 0.04 & 0.002 & 0.001 \\
\hline
\end{tabular}

(a) Two Standard deviations. 


\section{DISTRIBUTION}

No. of

Copies

$\underline{\text { OFFSITE }}$

A. A. Churm

DOE Patent Division

9800 South Cass Avenue

Argonne, IL 60439

27 DOE Technical Information Center

\section{ONSITE}

9 DOE Richland Operations Office

R. E. Austin

D. R. Elle (5)

H. E. Ransom

J. L. Rhoades

M. W. Tierrian

2 Rockwe 11 Hanford Operations

R. M. Mitche 11

D. L. Uh 1

1 Westinghouse Hanford Company

R. B. Hall
No. of

Copies

1 UNC Nuclear Industries, Inc.

P. A. Carlson

36 Pacific Northwest Laboratory

P. E. Bramson (2)

L. L. Cadwell

J. P. Corley

R. L. Dirkes

J. J. Fuquay

J. M. Kelley

H. V. Larson

R. W. Perkins

K. R. Price (14)

W. H. Rickard

G. A. Sehme 1

M. J. Sula

B. E. Vaughan

R. H. Williams

N. A. Wogman

Publishing Coordination $\mathrm{BE}(2)$

Technical Information (5) 